\title{
Assessment of risk factors associated with falls among the elderly in a municipality in the state of Paraíba, Brazil. A cross-sectional study
}

\author{
Alba Rejane Gomes de Moura Rodrigues', José Cesar Assef", Carlos Bezerra de Lima'"' \\ Primary Healthcare and Family Health Strategies, Patos (PB), Brazil
}

'BSN. Nurse and Doctoral Student of Surgical Research, Faculdade de Ciências Médicas da Santa Casa de São Paulo (FCMSCSP), São Paulo (SP); and Instructor, Unidade Acadêmica de Enfermagem (UAENF), Universidade Federal de Campina Grande (UFCG), Cajazeiras (PB), Brazil.

(D) orcid.org/0000-0003-1451-2114

"MD. Associate Professor, Department of Surgery, and Director of Emergency Services, Faculdade de Ciências Médicas da Santa Casa de São Paulo (FCMSCSP), São Paulo (SP), Brazil.

(D) orcid.org/0000-0001-7341-9003

"'BSN, MD. Nurse, Nursing Department, Universidade Federal do Rio de Janeiro (UFRJ), Rio de Janeiro (RJ); Teacher of Postgraduate Program, Faculdade Brasileira de Ensino Pesquisa e Extensão (FABEX), João Pessoa (PB), Brazil.

(D) orcid.org/0000-0001-6711-4676.

KEY WORDS:

Risk factors.

Aged.

Accidental falls.

\begin{abstract}
BACKGROUND: Falls among the elderly are one of the main public health problems that have direct consequences for their health. They reduce these individuals' autonomy and functional independence. OBJECTIVE: The objective of this study was to evaluate the risk factors associated with falls among elderly people enrolled within primary healthcare.

DESIGN AND SETTING: Cross-sectional study conducted at primary healthcare units in the municipality of Patos, state of Paraíba, Brazil.

METHODS: The Fall Risk Score and Timed Up and Go (TUG) test were used for evaluating the risk of falling among 316 elderly individuals. The independent variables used were sociodemographic and health conditions, while the dependent variable was the frequency of falls on the same level, over the course of previous years. The descriptive statistical tests used were the chi-square and Mann-Whitney tests.

RESULTS: Occurrence of falls was reported by 211 of the 316 participants, representing a prevalence of 66.8\% with confidence interval 61.6-72.0. The logistic regression results showed, after adjusting for all variables included in the model, that only the variables of vestibular disorders, self-assessed health status and dizziness/vertigo (trend) were significant $(P \leq 0.05)$. Most of the elderly participants had two or more associated pathological conditions. The participants were predominantly female (68.4\%).

CONCLUSIONS: Higher occurrence of falls was observed among female elderly individuals who suffered recurrent falls, had had low levels of schooling, presented comorbidities, had comorbidities and made use of drugs. These conditions predisposed these individuals to greater vulnerability to the risk of falls.
\end{abstract}

\section{INTRODUCTION}

The numbers of elderly people are growing rapidly. Both the community collectively and healthcare professionals, family members and caregivers individually need to reflect on their commitment towards dealing with the changes that occur as people become older. Aging is a natural, progressive and irreversible process that directly interferes with biological and functional conditions. Hence, one-off actions aimed at promoting healing and/or rehabilitation are insufficient. ${ }^{1}$

Statistical data show that Brazil has 20.6 million elderly people, representing $10.8 \%$ of its total population. By 2060 , this country's elderly population is expected to reach 58.4 million $(26.7 \%$ of the total population). ${ }^{2}$ Accordingly, guidance for actions to diminish the risk factors for falls in home settings will become very relevant.

The incidence of falls varies across countries. Studies conducted in Latin America and the Caribbean region have identified that, on an annual basis, the proportion of older adults suffering falls ranges from $21.6 \%$ in Barbados to $34 \%$ in Chile. ${ }^{3}$ These data emphasize that there is a need to take a more accurate look into the settings within which elderly people live. This is a major challenge, with regard both to identifying the elderly people who are at risk and to planning preventive strategies, irrespective of geographical location.

Falls are the sixth leading cause of death among people over 65 years old. They make these individuals fragile, insecure and unable to perform their daily activities for fear of falling again. ${ }^{4}$ Both intrinsic factors (physiological changes stemming from aging itself; presence of morbidities; and deficits in balance, vision, hearing or gait) and extrinsic factors (environmental risks due to poor lighting or inadequate or slippery floors; risk-prone behaviors, such as going upstairs and downstairs; and routine activities of daily living) play important roles. 
The multifactorial circumstances of this interaction of factors may predispose this group of vulnerable individuals to falls. ${ }^{5,6}$

Occurrences of falling have recently become a public health problem due to the complications resulting from them. They place a burden on the healthcare system and bring about physical mobility limitations. According to the Brazilian Ministry of Health, about $30 \%$ of people aged over 65 fall at least once a year. ${ }^{7}$ In a study conducted in Australia among elderly people living in the community, it was reported that $2-6 \%$ of falls were associated with fractures and approximately $1 \%$ of falls were associated with hip fractures. ${ }^{8}$

The municipality of Patos, in the state of Paraíba, was the scenario for the present study. A total of 426 hospital admissions due to falls were registered between January 2008 and December 2015 , which accounted for $6.9 \%$ of all hospitalizations. ${ }^{9}$ In addition to this high percentage of hospital admissions due to falls, this municipality does not have resources for rehabilitation, and no study on falls among the elderly had previously been conducted in this municipality. Recognizing the most vulnerable groups and acting so as to prevent falls by engaging the efforts of an interdisciplinary team can contribute towards minimizing these events. ${ }^{9}$

\section{OBJECTIVE}

The objective of this study was to assess the risk factors associated with falls among elderly people enrolled within primary healthcare in the municipality of Patos, Paraíba, Brazil.

\section{METHODS}

This was a quantitative cross-sectional study carried out between April and December 2016 at 40 family health units (Unidades de Saúde da Família, USF), among which 38 were located in the urban area and two in the rural area of the municipality of Patos, in the state of Paraíba, Brazil. The population sample size was calculated by considering a prevalence of falls of $30 \%$. This was in accordance with the national prevalence of falls in Brazil ${ }^{1,8}$ for a finite population of 13,453 elderly people. It was thus determined that a sample of 316 individuals would be needed.

A posteriori power calculations indicated that all the variables that were shown to be significantly associated in the logistic regression model had a statistical power of at least $94.8 \%$ for the sample size used in our study and the effect size we found (odds ratio-based).

The elderly participants were selected across the healthcare districts of the municipality by means of systematic sampling and by organizing a single listing of these districts. There are four healthcare districts in the municipality of Patos, each with ten healthcare units. The average number of elderly people per district was 3,200. The proportion of the sample across each of the four districts was calculated on this basis.
The sample selection process was then performed according to areas and micro-areas where community health agents acted, which, in turn, belonged to various census tracts (districts). Each community health agent had a spreadsheet containing data on their corresponding microarea, regarding street names, numbers of households per street with their respective full address and the estimated number of elderly people per household.

A draw was conducted among each five elderly people who had been selected to participate, based on the spreadsheet data. Thus, it was possible for more than one elderly person in the same household to participate in this study, given that individuals were selected, rather than their household. There were occurrences of situations in which two or more elderly people from the same household were selected to participate in the study, but only one of them was actually interviewed. Also, there were cases in which all the elderly people selected from a single household were interviewed. Overall, an average of 8-10 elderly people were selected from each healthcare unit. We did not have any dropouts or refusals.

The inclusion criteria were that the participants needed to be $\geq 60$ years of age and be resident in an area assigned to the units in question. Elderly people presenting some cognitive deficit, according to information provided by the community health agents, and those making use of any kind of device to aid walking, or a wheelchair, were excluded.

For data collection, two types of instruments were used. Firstly, a questionnaire was applied to gather sociodemographic data, with questions on gender, age, marital status, level of schooling, income and current occupation, among other data; and to gather self-reported information on the elderly participants' morbidities. Secondly, two fall risk assessment instruments were used: the Fall Risk Score, adapted from a study by Shiaveto, ${ }^{10}$ which uses five criteria to evaluate the risk of falls among the elderly population; and the TUG (Timed Up and Go) test, which assesses gait and balance.

In the TUG test, the time spent (in seconds) for the elderly individual to stand up from a seated position in a chair, walk a 3-meter distance, turn around, walk back towards the chair and sit down again was recorded. The individuals underwent this test once beforehand so that they could become familiar with it. They were given no assistance whatsoever as they took the test.

The Fall Risk Score evaluates the following: 1- Whether the elderly individuals had had any falls previously; 2- Whether they were using any medication; 3 - Whether they presented any sensory deficits; 4- Their mental state; and 5- Their gait.

The following independent variables were selected for this study: sociodemographic variables: (age, gender, marital status and schooling level); and health status variables: self-perception of health status, living alone, walking without difficulty, presence of changes (comorbidities), types of changes (comorbidities), 
medications (quantity and type) and other health hazards (dizziness/vertigo). The dependent variable was the frequency of falls from the same level over recent years.

The participants' cognitive ability was evaluated with the help of the Functional Activities Questionnaire (FAQ), devised by Pfeiffer. ${ }^{11}$ This scale was used in its version validated for use in Brazilian Portuguese. Cognitive ability was categorized as follows: absence of cognitive decline, or mild, moderate or severe critical decline. Elderly people with severe cognitive decline were excluded.

The interviews to administer the questionnaires were conducted by one author of the present study (ARGMR) and by three interviewers from the nursing undergraduate course who were enrolled in a course module on elderly people's healthcare and were trained and instructed on how to administer the questionnaire and its assessment grading scales. The interviews were conducted by means of visits to the elderly people's homes, which had previously been scheduled by the health agent in charge of the area where these elderly people lived.

Following data collection, a database was prepared in an Excel spreadsheet. To carry out the analysis, the database was exported from the Excel spreadsheet to the Statistical Package for the Social Sciences (SPSS) software, version 17.0. The data were then subjected to descriptive analysis (absolute and percentage frequencies), and the normality of age distribution was checked by means of the Shapiro-Wilk test, which showed that this variable did not follow normal distribution $(\mathrm{P}<0.05)$.

Subsequently, in order to check the association between occurrences of falls and each of the categorical variables, chi-square tests or Fisher's exact tests, as appropriate, were performed. To check whether there was an association between occurrences of falls and age, the non-parametric Mann-Whitney test was used. The variables that were found to be significantly associated with occurrences of falls were then fed into a logistic regression model to check the independent predictors of occurrences of falls, after adjustment for the other variables of the model. The significance level adopted for the statistical analysis was $\mathrm{P}<0.05$.

This study was approved by our institution's research ethics committee, through decision no. 962,318 (CAAE 38956414.000005181), on February 25, 2015, in accordance with Resolution No. 466/12 of Brazil's National Health Council (Conselho Nacional de Saúde).$^{12}$ All study participants were guaranteed that their participation would be voluntary, of their own free will, and were only included in the study after they had read and signed an informed consent statement. After informing illiterate elderly people about the objectives of the study, the person responsible for each individual in this situation who agreed to participate in the study was then asked to sign the voluntary consent form in lieu of this elderly individual.

\section{RESULTS}

Altogether, 316 elderly people were evaluated. Out of the total number of elderly people interviewed, $68.4 \%$ were females. The most prevalent age group was from 60 to 69 years old (40.5\%). The minimum age was 60 years, and the maximum age was 99 years, with a mean of 73 , median of 72 and standard deviation of 9 . The majority of the elderly people (64.7\%) had completed primary education, while $19.9 \%$ were illiterate. Regarding their marital status, $47.5 \%$ were married, $22.8 \%$ widowed and $15.8 \%$ were divorced.

Occurrence of falls in the period between 2015 and 2016 was reported by 211 of these 316 participants, thus representing a prevalence of $66.77 \%$, with a confidence interval (CI) of 61.672.0. Table 1 shows the distribution of the elderly people studied according to their sociodemographic variables and histories of falls. A significant association was found between occurrences of falls and schooling level $(\mathrm{P}=0.042)$. Among the individuals who sustained falls, there was a greater proportion who were illiterate or who had only completed primary education. No significant differences were found in relation to the other demographic variables.

With regard to the possible risk factors for occurrences of falls, comorbidities and self-assessed health status were evaluated (Table 2). Among the self-reported pre-existing chronic

Table 1. Distribution of the elderly people studied, according to sociodemographic variables and history of falls. Patos (PB), 2016

\begin{tabular}{|c|c|c|c|c|}
\hline $\begin{array}{l}\text { Sociodemographic } \\
\text { variables }\end{array}$ & \multirow[t]{2}{*}{ Categories } & No falls & With falls & \multirow[t]{2}{*}{$\mathbf{P}$} \\
\hline n & & $n=105$ & $n=211$ & \\
\hline \multirow{2}{*}{ Gender } & Male & $35(33.3)$ & $65(30.8)$ & \multirow{2}{*}{0.744} \\
\hline & Female & $70(66.7)$ & $146(69.2)$ & \\
\hline \multirow{4}{*}{ Marital status } & Single & $10(9.5)$ & $34(16.1)$ & \multirow{4}{*}{0.335} \\
\hline & Married & $55(52.4)$ & $95(45.0)$ & \\
\hline & Divorced & $18(17.1)$ & $32(15.2)$ & \\
\hline & Widowed & $22(21.0)$ & $50(23.7)$ & \\
\hline \multirow{8}{*}{ Schooling level } & Illiterate & $13(12.4)$ & $50(23.7)$ & \multirow{8}{*}{0.042} \\
\hline & $\begin{array}{c}\text { Incomplete } \\
\text { primary } \\
\text { education }\end{array}$ & $55(52.4)$ & 101 (47.9) & \\
\hline & $\begin{array}{c}\text { Completed } \\
\text { primary } \\
\text { education }\end{array}$ & $12(11.4)$ & $32(15.2)$ & \\
\hline & $\begin{array}{l}\text { Incomplete } \\
\text { secondary }\end{array}$ & $2(1.9)$ & $4(1.9)$ & \\
\hline & education & & & \\
\hline & $\begin{array}{l}\text { Completed } \\
\text { secondary } \\
\text { education }\end{array}$ & $13(12.4)$ & $11(5.2)$ & \\
\hline & $\begin{array}{l}\text { Incomplete } \\
\text { higher } \\
\text { education }\end{array}$ & $0(0.0)$ & $1(0.5)$ & \\
\hline & $\begin{array}{c}\text { Completed } \\
\text { higher } \\
\text { education }\end{array}$ & $10(9.5)$ & $12(5.7)$ & \\
\hline
\end{tabular}


comorbidities or diseases, the proportions of these that showed associations with other pathological conditions were as follows: systemic arterial hypertension (81.5\%), arthrosis (37.9\%) and vestibular disorders (33.2\%).

Self-assessed health status showed a statistically significant association with occurrences of falls among the elderly people who

Table 2. Association between comorbidities and presence of falls. Patos (PB), 2016

\begin{tabular}{|c|c|c|c|c|}
\hline \multirow{2}{*}{ Comorbidities } & \multirow{2}{*}{ Categories } & No falls & With falls & \multirow{2}{*}{$P$} \\
\hline & & $n=105$ & $n=211$ & \\
\hline \multirow{2}{*}{ Diabetes } & No & 76 (72.4) & $129(61.1)$ & \multirow{2}{*}{0.065} \\
\hline & Yes & $29(27.6)$ & $82(38.9)$ & \\
\hline \multirow{2}{*}{ Hypertension } & No & $33(31.4)$ & 39 (18.5) & \multirow{2}{*}{0.015} \\
\hline & Yes & $72(68.6)$ & $172(81.5)$ & \\
\hline \multirow{2}{*}{ Stroke } & No & $104(99.0)$ & $201(95.3)$ & \multirow{2}{*}{0.108} \\
\hline & Yes & $1(1.0)$ & $10(4.7)$ & \\
\hline \multirow{2}{*}{$\begin{array}{l}\text { Low blood } \\
\text { pressure }\end{array}$} & No & $100(95.2)$ & $206(97.6)$ & \multirow{2}{*}{0.309} \\
\hline & Yes & $5(4.8)$ & $52.4)$ & \\
\hline \multirow{2}{*}{ Heart disease } & No & $91(86.7)$ & $164(77.7)$ & \multirow{2}{*}{0.081} \\
\hline & Yes & $14(13.3)$ & $47(22.3)$ & \\
\hline \multirow{2}{*}{$\begin{array}{l}\text { Neurological } \\
\text { disease }\end{array}$} & No & $103(98.1)$ & $201(95.3)$ & \multirow{2}{*}{0.349} \\
\hline & Yes & $2(1.9)$ & $10(4.7)$ & \\
\hline \multirow{2}{*}{ Insomnia } & No & $90(85.7)$ & $174(82.5)$ & \multirow{2}{*}{0.567} \\
\hline & Yes & $15(14.3)$ & $37(17.5)$ & \\
\hline \multirow{2}{*}{ Hypothyroidism } & No & $103(98.1)$ & 194 (91.9) & \multirow[t]{2}{*}{0.055} \\
\hline & Yes & $2(1.9)$ & $17(8.1)$ & \\
\hline \multirow{2}{*}{ Depression } & No & $93(88.6)$ & $184(87.2)$ & \multirow{2}{*}{0.868} \\
\hline & Yes & $12(11.4)$ & $27(12.8)$ & \\
\hline \multirow{2}{*}{ Arthritis } & No & $86(81.9)$ & $159(75.4)$ & \multirow{2}{*}{0.242} \\
\hline & Yes & $19(18.1)$ & $52(24.6)$ & \\
\hline \multirow{2}{*}{ Arthrosis } & No & $82(78.1)$ & $131(62.1)$ & \multirow{2}{*}{0.006} \\
\hline & Yes & $23(21.9)$ & $80(37.9)$ & \\
\hline \multirow{2}{*}{$\begin{array}{l}\text { Vestibular } \\
\text { disorders }\end{array}$} & No & $92(87.6)$ & $141(66.8)$ & \multirow{2}{*}{$<0.001$} \\
\hline & Yes & $13(12.4)$ & $70(33.2)$ & \\
\hline \multirow{2}{*}{ Incontinence } & No & $104(99.0)$ & $199(94.3)$ & \multirow{2}{*}{0.067} \\
\hline & Yes & $1(1.0)$ & $12(5.7)$ & \\
\hline \multirow{2}{*}{ Anxiety } & No & $85(81.0)$ & $168(79.6)$ & \multirow{2}{*}{0.897} \\
\hline & Yes & $20(19.0)$ & $43(20.4)$ & \\
\hline & No & $70(66.7)$ & $113(53.6)$ & \\
\hline 0 & Yes & $35(33.3)$ & $98(46.4)$ & 0.0 \\
\hline
\end{tabular}

participated in our study. When asked about how they assessed their own health status, $45.6 \%$ considered it good; $26.6 \%$, normal; and $26.3 \%$, very good. A significant association was found between occurrences of falls and self-assessed health status $(\mathrm{P}<0.001)$. Among the individuals who suffered falls, there were higher proportions with good and normal health status, whereas among individuals who reported not falling, there was a higher proportion with very good health status (Table 3 ).

Because the elderly participants still had a fairly independent and autonomous lifestyle, they self-identified as independent. However, they suffered falls more often probably because they enjoyed walking around, given that they felt more self-confident and did not fear being exposed to risk factors (Table 3). In this study, the prevalence of falls was higher among the elderly people who self-assessed their health status as good.

Among the individuals evaluated, significant associations were found between occurrences of falls and occurrences of comorbidities and use of medications. Use of several medications was another trait found in our study among the elderly people who sustained falls (Table 4).

Significant associations were found between occurrences of falls and use of medications, quantity of medications, use of antihypertensive drugs and use of analgesics. Among individuals who suffered falls, there were higher proportions of use of medications, quantity of medications and use of antihypertensives and analgesics.

\section{Logistic regression analysis}

The variables that were significantly associated with occurrences of falls in the univariate analysis underwent logistic regression analysis, in which occurrence of falls was used as a dependent variable. The aim of this analysis was to identify which variables were independent predictors of occurrence of falls, with adjustment for all other variables included in the model. Because of the strong association between the variables of use of medications and dosages of medications, only the variable of use of medications was included in the final model. This decision was

Table 3. Distribution of the elderly people according to the occurrence of falls, in relation to the variable of health status assessment in the municipality of Patos (PB), 2016

\begin{tabular}{|c|c|c|c|c|c|c|c|}
\hline \multirow{2}{*}{$\begin{array}{l}\text { Health status } \\
\text { assessment }\end{array}$} & \multicolumn{2}{|c|}{ Overall } & \multicolumn{2}{|c|}{ lo falls } & \multicolumn{2}{|c|}{ With falls } & \multirow{2}{*}{$\mathbf{P}^{1}$} \\
\hline & $\mathrm{n}$ & $\%$ & $\mathrm{n}$ & $\%$ & $\mathrm{n}$ & $\%$ & \\
\hline Very good & 83 & 26.3 & 53 & 63.9 & 30 & 36.1 & \multirow{5}{*}{$<0.001$} \\
\hline Good & 144 & 45.6 & 38 & 26.4 & 106 & 73.6 & \\
\hline Normal & 84 & 26.6 & 13 & 15.5 & 71 & 84.5 & \\
\hline Poor & 3 & 0.9 & 1 & 33.3 & 2 & 66.7 & \\
\hline Very poor & 2 & 0.6 & 0 & 0.0 & 2 & 100 & \\
\hline
\end{tabular}

'Chi-square test. 
necessary in order to avoid multicollinearity in the model, thus allowing for thorough implementation (Table 5).

From the logistic regression analysis, it could be seen that, after adjustment for all variables included in the model, only the variables of vestibular disorders, self-assessed health status and dizziness/vertigo (trend) were significant. Interpretation of odds ratios

Table 4. Distribution of medication-related factors, in relation to occurrences of falls. Patos (PB), 2016

\begin{tabular}{|c|c|c|c|c|}
\hline Medications & Catenorioc & No falls & With falls & P \\
\hline$n$ & caleguries & 105 & 211 & $r$ \\
\hline \multirow{2}{*}{ Use of medications } & No & $17(16.2)$ & $8(3.8)$ & \multirow{2}{*}{$<0.001$} \\
\hline & Yes & $88(83.8)$ & $203(96.2)$ & \\
\hline \multirow{3}{*}{ Number of medications } & 1 to 2 & $74(84.1)$ & $130(64.0)$ & \multirow{3}{*}{0.002} \\
\hline & 3 to 4 & $12(13.6)$ & $52(25.6)$ & \\
\hline & 5 & $2(2.3)$ & $21(10.3)$ & \\
\hline \multirow{2}{*}{ Use of antihypertensives } & No & $33(31.4)$ & $39(18.5)$ & \multirow{2}{*}{0.015} \\
\hline & Yes & $72(68.6)$ & $172(81.5)$ & \\
\hline \multirow{2}{*}{$\begin{array}{l}\text { Use of hypoglycemic agents/ } \\
\text { insulin agents }\end{array}$} & No & $77(73.3)$ & $133(63.0)$ & \multirow{2}{*}{0.089} \\
\hline & Yes & $28(26.7)$ & $78(37.0)$ & \\
\hline \multirow{2}{*}{ Use of diuretics } & No & $99(94.3)$ & $189(89.6)$ & \multirow{2}{*}{0.239} \\
\hline & Yes & $6(5.7)$ & $22(10.4)$ & \\
\hline \multirow{2}{*}{ Use of analgesics } & No & $70(66.7)$ & $108(51.2)$ & \multirow{2}{*}{0.013} \\
\hline & Yes & 35 (33.3) & $103(48.8)$ & \\
\hline \multirow{2}{*}{ Use of sedatives } & No & $102(97.1)$ & $202(95.7)$ & \multirow{2}{*}{0.757} \\
\hline & Yes & $3(2.9)$ & $9(4.3)$ & \\
\hline \multirow{2}{*}{ Use of antidepressants } & No & $105(100.0)$ & $207(98.1)$ & \multirow{2}{*}{0.306} \\
\hline & Yes & $0(0.0)$ & $4(1.9)$ & \\
\hline
\end{tabular}

(OR) showed that individuals with vestibular disorders presented a 2.23-fold greater risk of falling than those without vestibular disorders. Furthermore, in relation to individuals with very good health status, individuals with good health status had a 3.53-fold higher risk of falling; and individuals with normal health status had a 5.45-fold greater risk of falling. Lastly, individuals with dizziness/vertigo had a 1.87-fold greater risk of falling, in relation to individuals without dizziness/vertigo.

The presence of vestibular disorders, imperfect self-assessed health status and presence of dizziness/vertigo were independent predictors for occurrence of falls. The other predictors, while being statistically significant when evaluated separately through logistic regression, were not statistically relevant.

\section{DISCUSSION}

In this study, the prevalence of the occurrence of falls in the period between 2015 and 2016 was $66.77 \%$. We found that $91.2 \%$ of the sample was using some sort of medication, mainly for controlling systemic arterial hypertension, diabetes mellitus or pain. Use of drugs and presence of diseases are two risk factors for occurrences of falls. ${ }^{10}$ The prevalence of falls was higher among females and older individuals with lower schooling levels.

The prevalence of falls last year $(66.77 \%)$, as found in this study, can be considered high, in comparison with other Brazilian studies, in which the reported prevalence has ranged from $28 \%$ to $37.5 \% \cdot{ }^{13-15}$ In a systematic review of the literature, Sandoval

Table 5. Logistic regression analysis using occurrence of falls as a dependent variable. Patos (PB), 2016

\begin{tabular}{|c|c|c|c|c|c|c|}
\hline Variable & Beta & SE beta & OR & $\begin{array}{c}95 \% \mathrm{Cl} \\
\text { lower limit }\end{array}$ & $\begin{array}{c}95 \% \mathrm{Cl} \\
\text { upper limit }\end{array}$ & $\mathbf{P}$ \\
\hline (Intercept) & -3.677 & 1.522 & 0.03 & 0.00 & 0.48 & 0.016 \\
\hline Schooling level: incomplete primary education & -0.081 & 0.420 & 0.92 & 0.40 & 2.08 & 0.846 \\
\hline Schooling level: incomplete secondary education & -0.245 & 1.091 & 0.78 & 0.10 & 8.16 & 0.822 \\
\hline Schooling level: completed secondary education & -0.427 & 0.606 & 0.65 & 0.20 & 2.14 & 0.481 \\
\hline Age & 0.031 & 0.019 & 1.03 & 0.99 & 1.07 & 0.096 \\
\hline Systemic arterial hypertension (yes) & -0.298 & 1.043 & 0.74 & 0.09 & 6.07 & 0.775 \\
\hline Arthrosis (yes) & 0.362 & 0.319 & 1.44 & 0.77 & 2.71 & 0.256 \\
\hline Vestibular disorder (yes) & 0.801 & 0.400 & 2.23 & 1.04 & 5.03 & 0.045 \\
\hline Osteoporosis (yes) & 0.244 & 0.297 & 1.28 & 0.71 & 2.29 & 0.410 \\
\hline Health status assessment: normal & 1.696 & 0.438 & 5.45 & 2.35 & 13.19 & $<0.001$ \\
\hline Health status assessment: poor & 0.634 & 1.400 & 1.89 & 0.13 & 50.31 & 0.650 \\
\hline Health status assessment: terrible & 15.668 & 1023.691 & $\operatorname{lnf}$ & 0.00 & NA & 0.988 \\
\hline Dizziness/vertigo (yes) & 0.625 & 0.318 & 1.87 & 1.00 & 3.51 & 0.050 \\
\hline
\end{tabular}

$\mathrm{SE}=$ standard error; $\mathrm{OR}=$ odds ratio; $\mathrm{Cl}=$ confidence interval. 
et al. ${ }^{16}$ found that the prevalence of falls among elderly residents living in the community ranged from $15.9 \%$ to $56.3 \%$. A lower prevalence was found in the United States, while the highest prevalence was found in Brazil. In Europe, and more specifically in Spain and Italy, the prevalence was found to be $30.5 \%$ to $31.8 \% .^{17}$ In Africa, a study conducted in Nigeria showed a prevalence of $23 \%{ }^{18}$ In Asia, a study conducted in China showed a prevalence of $26.4 \%{ }^{19}$ Differences in prevalence between studies have not been analyzed in depth and may have been caused by different study designs and varying methodologies.

With regard to self-reported pre-existing chronic comorbidities or diseases, the proportions of these that showed associations with other pathological conditions were as follows: systemic arterial hypertension (77.2\%), osteoporosis (42.1\%), diabetes (35.1\%), arthrosis (32.6\%), vestibular disorders (26.3\%), anxiety (22.5\%) and urinary incontinence $(92.3 \%)$. It is important to emphasize that the elderly participants could choose to report the presence of more than one comorbidity. Among those that we evaluated, systemic arterial hypertension, osteoporosis, diabetes, arthrosis, vestibular disorders, thyroid problems and urinary incontinence were statistically significant for the risk of falls.

In the present study, we found that the elderly participants had low levels of schooling, and that $49.4 \%$ had not finished elementary school. This was found to be relevant regarding occurrences of falls. Lopes, ${ }^{20}$ in Uberaba, in the state of Minas Gerais, Brazil, also found a high percentage of low levels of schooling among elderly people living in the community, and that $43.1 \%$ of them were illiterate. The percentage in their study was slightly lower than what we found in our study, but it was still a significant predictor of falls in that population. In a cohort study conducted on 1,415 elderly people in the city of São Paulo, Brazil, Perracini and $\operatorname{Ramos}^{21}$ found that most of the elderly people who had had falls were illiterate and fell recurrently. Their finding was similar to our own in this study. Marin et al. ${ }^{22}$ and Freitas et al. ${ }^{23}$ also considered that the level of schooling was an important factor that deserved to be highlighted, since it might have made it more difficult to provide care services, given that such clients would be less involved in their own care and in the risk prevention process.

Development of multiple chronic pathological conditions and comorbidities are among the consequences that accompany aging, along with intake of various medications. Chronic diseases can most often cause systemic problems that require regular use of more than one medication, and this contributes towards occurrences of falls.

The presence of comorbidities is a risk factor, and systemic arterial hypertension is an aggravating factor for the risk of falls and fractures. Hence, given the high prevalence of systemic arterial hypertension in the population of the present study, there is a need for hypertensive patients to be better monitored for the pharmacological interactions among antihypertensive drugs, by medical and healthcare professionals. The aim in doing this is both to improve their health status and to reduce the occurrence of falls. ${ }^{24}$

Tests to assess the decline in visual function with age were not used in the present study because most of the elderly participants did not report any complaints regarding their vision. We consider this to be a weak point in the present study.

In assessing patients using Dowton's Fall Risk Score scale, ${ }^{10}$ we found that among the elderly people who had reported previous falls, such reports were more frequent among those who had been using hypertensive medications. Regarding the time that these individuals took to do the TUG test, their average time was found to be $11.4 \mathrm{~s}$ and the standard deviation was $3.5 \mathrm{~s}$. Upon applying the TUG cutoffs, most of these elderly people, i.e. 177 (56.0\%) were classified as being at medium risk of falls.

Several studies have addressed medications as a major risk factor for falls. In a study carried out in Ribeirão Preto, in the state of Sao Paulo, Brazil, Fabrício et al. ${ }^{25}$ observed that $70 \%$ of the elderly participants were using some type of medication before falling and that $42 \%$ of them used polypharmacy. This corroborates our findings.

The main causes of falls that were self-reported by the elderly participants were the following: dizziness (42.7\%), carelessness (24.2\%), slipping (14.7\%), imbalance (11.8\%) and alcohol consumption (3.8\%). We were able to group these causes into extrinsic and intrinsic factors that led to falls. The intrinsic factors of dizziness and (to a smaller but significant extent) imbalance predominated and were more prevalent than the extrinsic factors. This corroborate the findings of Fhon, ${ }^{26}$ who also observed higher prevalence of intrinsic risk factors. Among the extrinsic factors, carelessness and slipping can, according to Guimarães, ${ }^{27}$ be triggered by the aging process. This process alters gait patterns, limits the amplitude of dorsiflexion of the ankles and reduces strength.

Despite the significant aspects of falls among the elderly and their associated factors that were identified in our study, memory bias may have interfered in the results from this evaluation, given that the occurrences of falls recorded here were based on self-reports. The cross-sectional design was also one of the limitations of the study, since this design does not allow for direct assessment of the possible cause and effect relationship between the predictors of falls. Nevertheless, the direction and magnitude of these associations may contribute towards identifying important risk factors that are useful for preventing occurrences of these falls among the elderly at home.

\section{CONCLUSION}

Falls and fractures among elderly people are multifactorial. This study showed that the prevalence of falls was high and associated with comorbidities. High blood pressure was found to be a preponderant risk factor. Therefore, interdisciplinary actions to meet the needs of the elderly are essential for preventing falls. 


\section{REFERENCES}

1. Schneider ARS. Envelhecimento e quedas: a fisioterapia na promoção e atenção à saúde do idoso. RBCEH. 2010;7(2):296-303. doi: 10.5335/ rbceh.2012.414.

2. Instituto Brasileiro de Geografia e Estatística. IBGE. Síntese de indicadores sociais. Uma análise das condições de vida da população brasileira 2010. Rio de Janeiro: IBGE; 2010. Available from: http://www.ibge.gov. br/home/estatistica/populacao/condicaodevida/indicadoresminimos/ sinteseindicsociais2010/default.shtm. Accessed 2018 (Aug 20).

3. Reyes-Ortiz CA, Al Snih S, Markides KS. Falls among elderly persons in Latin America and the Caribbean and among elderly MexicanAmericans. Rev Panam Salud Pública. 2005;17(5-6):362-9. PMID: 16053646; doi: 10.1590/s1020-49892005000500008.

4. Brasil. Ministério da Saúde. Secretaria de Vigilância em Saúde. Departamento de Análise de Situação em Saúde. Saúde Brasil 2011:uma análise da situação de saúde e de evidências selecionadas de impacto de ações de vigilância em saúde. Brasília (DF): Ministério da Saúde; 2012. Available from: http://bvsms.saude.gov.br/bvs/publicacoes/ saude_brasil_2011.pdf. Accessed in 2019 (Jul 1).

5. Nicolussi AC, Fhon JR, Santos CA, et al. Qualidade de vida em idosos que sofreram quedas: revisão integrativa da literatura [Quality of life in elderly people that have suffered falls: integrative literature review]. Ciênc Saúde Coletiva. 2012;17(3):723-30. PMID: 22450414; doi: 10.1590/ S1413-81232012000300019.

6. Lima DWC, Cruz AMM, Morais FMP, Torres ADM, Freitas MC. Impact of a fall in the elderly: an analysis of the risk factors. Rev Rene. 2013; 14(4):929-37. Available from: http://www.periodicos.ufc.br/rene/article/ view/3622/2864. Accessed in 2018 (Dec 20).

7. Brasil. Ministério da Saúde. Secretaria de Atenção à Saúde. Departamento de Atenção Básica. Envelhecimento e saúde da pessoa idosa/Ministério da Saúde, Secretaria de Atenção à Saúde, Departamento de Atenção Básica. Brasília: Ministério da Saúde, 2006. Available from: http://bvsms. saude.gov.br/bvs/publicacoes/abcad19.pdf. Accessed in 2019 (Jul 1).

8. Lord SR, Menz HB, Tiedemann A. A physiological profile approach to falls risk assessment and prevention. Phys Therapy. 2003;83(3):237-52. PMID: 12620088; doi: 10.1093/ptj/83.3.237.

9. DATASUS. Sistema de Informações Hospitalares do SUS (SIH/SUS). Situação da base de dados nacional em 30/03/2016. Dados de fevereiro de 2015 até fevereiro de 2016 sujeitos a retificação. Brasília (DF): Ministério da Saúde; 2016. Available from: http://tabnet.datasus. gov.br/cgi/deftohtm.exe?sih/cnv/fipb.def. Accessed in 2019 (Jul 1).

10. Schiaveto FV. Avaliação do risco de quedas em idosos na comunidade [dissertation]. Ribeirão Preto: Escola de Enfermagem de Ribeirão Preto, Universidade de São Paulo; 2008. doi: 10.11606/D.22.2008. tde-19122008-153736.

11. Pfeffer RI, Kurosaki TT, Harrah CH Jr, Chance JM, Filos S. Measurement of functional activities in older adults in the community. J Gerontol. 1982;37(3):323-9. PMID: 7069156 doi: 10.1093/geronj/37.3.323.
12. Brasil. Ministério da Saúde. Resolução no 466, de 12 de dezembro de 2012, do Conselho Nacional de Saúde. Brasília (DF): Ministério da Saúde; 2012. Available from: http://bvsms.saude.gov.br/bvs/saudelegis/ cns/2013/res0466_12_12_2012.html. Accessed 2018 (Aug 20).

13. Siqueira FV, Facchini LA, Piccin RX, et al. Prevalência de quedas em idosos e fatores associados [Prevalence of falls and associated factors in the elderly]. Rev Saude Publica. 2007;41 (5):749-56. PMID: 17923896; doi: 10.1590/S0034-89102007000500009.

14. Motta LB, Aguiar AC, Coutinho ESF, Huf G. Prevalência e fatores associados a quedas em idosos em um município do Rio de Janeiro. Rev Bras Geriatr Gerontol. 2010;13(1):83-91. doi: 10.1590/S180998232010000100009

15. Soares WJS, Moraes SA, Ferriolli E, Perracini MR. Fatores associados a quedas e quedas recorrentes em idosos: estudo de base populacional. Rev Bras Geriatr Gerontol. 2014;17(1):49-60. doi: 10.1590/S180998232014000100006

16. Sandoval RA, Sá ACAM, Menezes RL, Nakatani AYK, Bachion MM. Ocorrência de quedas em idosos não institucionalizados: revisão sistemática da literatura. Rev Bras Geriatr Gerontol. 2013;16(4):855-86. doi: 10.1590/S1809-98232013000400019.

17. Varas-Fabra F, Castro Martín E, Torres LAP, Fernández MJ, Moral RR, Berge IE. Caídas en ancianos de la comunidad: prevalencia, consecuencias y factores asociados. Aten Primaria. 2006;38(8):450-5. doi: $10.1157 / 13094802$

18. Bekibele CO, Gureje O. Fall incidence in a population of elderly persons in Nigeria. Gerontology. 2010;56(3):278-83. doi: 10.1159/000236327.

19. Chu LW, Chiu AY, Chi I. Falls and subsequent health service utilization in community-dwelling Chinese older adults. Arch Gerontol Geriatr. 2008;46(2):125-35. PMID: 17467081; doi: 10.1016/j. archger.2007.03.005

20. Lopes FAM, Montanholi LL, Silva JML, Oliveira FA. Perfil epidemiológico em idosos assistidos pela estratégia saúde da família [The epidemiological profile of elderlies cared for by the Family Health Strategy]. Rev Enferm Atenção Saúde. 2014;3(1):84-94. Available from: http://seer.uftm.edu.br/ revistaeletronica/index.php/enfer/article/download/933/665. Accessed in 2018 (Aug 20)

21. Perracini MR, Ramos LR. Fatores associados a quedas em uma coorte de idosos residentes na comunidade [Fall-related factors in a cohort of elderly community residents]. Rev Saúde Pública. 2002;36(6)709-16. PMID: 12488937; doi: 10.1590/S0034-89102002000700008.

22. Marin MJS, Candido DV, Myazato JM, Castilho NC, Ribeiro PC. Características dos riscos para quedas entre idosos de uma unidade de saúde da família [Characteristics of fall risks among the elderly in a family health unit]. REME Rev Min Enferm. 2007;11(4):369-74. Available from: http://reme.org.br/exportar-pdf/359/v11 n4a04.pdf. Accessed in 2018 (Aug 20).

23. Freitas EV, Py L, Neri AL, et al. Tratado de geriatria e gerontologia. 3a ed. Rio de Janeiro: Guanabara Koogan; 2011. ISBN: 9788527719056. 
24. Soares IGE, Rech V. Prevalência de quedas em idosos institucionalizados no Brasil: uma revisão integrativa. Rev Kairós Gerontol. 2015;18(4):4761. Available from: https://revistas.pucsp.br/index.php/kairos/article/ download/26892/19102. Accessed in 2018 (Aug 20).

25. Fabrício SC, Rodrigues RA, da Costa ML Jr. Causas e consequências de quedas de idosos atendidos em hospital público [Falls among older adults seen at a São Paulo State public hospital: causes and consequences]. Rev Saúde Pública. 2004;38(1):93-9. PMID: 14963547; doi: 10.1590/S0034-89102004000100013.

26. Fhon JRS, Fabrício-Wehbe SCC, Vendruscolo TRP, et al. Quedas em idosos e sua relação com a capacidade funcional. Rev Latino-Am Enfermagem. 2012;20(5):927-34. Available from: http://www.scielo. br/pdf/rlae/v20n5/pt_15.pdf. Accessed in 2018 (Aug 20).

27. Guimarães JMN, Farinatti PTV. Análise descritiva de variáveis teoricamente associadas ao risco de quedas em mulheres idosas [Descriptive analysis of variables theoretically associated to the risk of falls in elder women]. Rev Bras Med Esporte. 2005;1 1(5):299-305. doi: 10.1590/S1517-86922005000500011.

\section{Sources of funding: None}

Conflicts of interest: None

Date of first submission: October 19, 2017

Last received: April 23, 2019

Accepted: June 12, 2019

\section{Address for correspondence:}

Alba Rejane Gomes de Moura Rodrigues

Faculdade de Ciências Médicas da Santa Casa de São Paulo (FCMSCSP)

Rua Dr. Cesário Motta Jr., 61

Vila Buarque - São Paulo (SP) - Brasil

CEP 01221-020

Tel. (+55 11) 3367-7700

E-mail: rejanegomesmoura@gmail.com 